\title{
Status for miljørigtigt idrætsbyggeri i Danmark
}

\author{
Af Bente Mortensen
}

\section{Indledning}

Idrætsforeninger og kommuner tager ikke gennemgribende miljøhensyn eller stiller konkrete miljøkrav, når der bygges nye faciliteter til idrætsformål. Der er kun få eksempler på initiativer, der har til formål at skabe et miljørigtigt eller bæredygtigt idrætsbyggeri.

Der findes mange gode eksempler på enkelttiltag med brug af energimærkede vinduer, rumfølere til at tænde og slukke lyset i omklædningslokaler og opsætning af lavtskyls-toiletter. Men det er alt sammen forandringer i det små. I langt de fleste tilfælde bliver miljøhensyn ikke betragtet som en naturlig del af kvaliteten, når der bygges idrætsanlæg, og der er ikke lagt op til radikale forandringer, som kan være med til at påvirke udviklingen i en mere bæredygtig retning, dvs. at tage hensyn til både miljø, mennesker og $\varnothing$ konomi.

Formålet med denne artikel er at kortlægge, i hvilken udstrækning de forskellige aktører på området f.eks. idrætsforeninger, organisationer, kommuner og rådgivere tager miljøhensyn ved planlægning og drift af idrætsbyggeri i Danmark samt pege på eventuelle forbedringsmuligheder.

Der er gjort rede for de faktorer, der i forbindelse med etablering og drift af idrætsfaciliteter har betydning for påvirkningen af natur og miljø. Med afsæt i enkelte konkrete cases om miljørigtigt id- rætsbyggeri følger en gennemgang af primært de danske idrætsforeningers og andre relevante organisationers indsats på området. De offentlige myndigheders formelle og reelle opgaver berøres også, ligesom det diskuteres, hvem der har ansvaret for, at miljø bliver en del af kvaliteten ved fremtidens idrætsbyggeri, og hvad aktører som f.eks. bygherre kan gøre.

\section{Status for idraetsbyggeriet $i$ Danmark}

Idrætsbyggeriet boomede i 1960'erne og 70'erne, hvor mange nye idrætsanlæg og især mange ensartede haller blev bygget. Der blev primært fokuseret på $\emptyset$ konomien $\mathrm{i}$ mange af disse byggerier. I dag er mange haller nedslidte og i teknisk dårlig stand, og der er problemer med indeklimaet. ${ }^{1}$ Reparation og ombygning er nødvendigt.

Udviklingen er gået i retning af en mere tværfunktionel brug af faciliteter og lokaler ikke kun til idrætsformål, men også til en blanding af idræts- og kulturformål og mere multianvendelige huse, hvor der er lagt op til, at de traditionelle skel mellem idrætslige og kulturelle anvendelser nedbrydes, som det ses i forbindelse med projekter i Næstved, Hadsten og på Frederiksberg. ${ }^{2}$

Ses på de traditionelle idrætsanlæg til f.eks. boldspil, gymnastik, svømning og 


\begin{tabular}{lll} 
& Offentligt ejede & Privatejede \\
\hline Haller og idrætslokaler & 2603 & 962 \\
\hline Svømmefaciliteter & 243 & 190 \\
\hline Boldbaner & 5286 & 530 \\
\hline Skøjtefaciliteter & 43 & 7 \\
\hline Atletikfaciliteter & 469 & 33 \\
\hline Total & 8644 & 1722 \\
\hline
\end{tabular}

Idratshaller og -anlag Lokale- og Anlaegsfondens facilitetsstatistik, 2004

skpjtning findes der over 10.000 idrætshaller og -anlæg i Danmark. ${ }^{3}$ Over halvdelen af disse er anlæg til fodbold og størstedelen af hallerne er bygget til håndbold.

Hovedparten (over $83 \%$ ) af de eksisterende haller er offentligt ejet, og driften er afhængig af tilskud fra stat og kommuner.

\section{Befolkningens idratsdeltagelse}

Idræts- og friluftsaktiviteter udgør en særlig og voksende del af danskernes fritid og foregår både i dagligdagen som korterevarende aktiviteter nær bopælen og i form af aktiviteter under ophold væk fra de hjemlige omgivelser.

Danskernes fysiske aktiviteter er vokset i løbet af de sidste årtier, idet udøvelse af sport og motion er steget fra $15 \%$ hos den voksne befolkning i 1964 til 48\% i 1993 og $59 \%$ i $2002 .{ }^{4}$ De væsentligste grunde til at dyrke idræt er at få et »godt helbred « og at deltage $i$ et »fællesskab«. Faktorer som »præstation $«$ og »konkurrence « spiller en langt mindre rolle for deltagelsen. ${ }^{5}$

Idrætsudøvere er ikke længere trofaste og loyale. De vil hellere prøve mange forskellige sportsgrene og har fået større frihed til at gøre det i takt med velfærdsstigningen i samfundet. ${ }^{6}$

Udviklingen af mange forskellige for- mer for sportsgrene og forventningen om højere serviceniveau og større bekvemmelighed stiller større krav til faciliteter og lokaler i dag end tidligere.

Idræt kan have stor betydning for et lokalsamfund. Tilbud om idrætsaktiviteter er god service over for borgerne, giver god mulighed for at mødes og kan være et vigtigt aktiv for nye tilflyttere. ${ }^{7}$

Sport er en branche, hvor der omsættes for milliarder af kroner, og det er samtidig blevet et varemærke, som kan udnyttes, som det f.eks. sker inden for håndbold, fodbold og golf.

Andre steder i verden f.eks. i Barcelona og Manchester er store idrætsbegivenheder og unikke stadions blevet udgangspunktet for en omfattende byudvikling og et middel til at markedsføre sig globalt i forhold til turisme og udefra kommende investeringer. ${ }^{8}$

For en by eller et lokalområde kan en international begivenhed være et betydeligt aktiv. Effektanalyser fra Danmarks Turistråd viser, at større nationale og internationale idrætsbegivenheder, der afholdes $\mathrm{i}$ Danmark, har en positiv indflydelse på $\emptyset$ konomien og beskæftigelsen både lokalt og nationalt $\mathrm{i}$ form af flere overnatninger, bespisning, transport og indk $\varnothing \mathrm{b}$. De store arrangementer har selvfølgelig også en miljømæssig betydning, men dette indgår ikke i disse analyser. ${ }^{9}$ 


\section{Påvirker idrat miljфet?}

Idræt har lokalt og globalt en række miljømæssige, sociale og økonomiske konsekvenser. De positive påvirkninger er f.eks. muligheden for socialt samvær, sundhed, livskvalitet, jobskabelse, vedligeholdelse af små samfund samt faciliteter, der kommer den lokale befolkning til gode. Idrætsaktiviteterne har samtidig en række negative påvirkninger af miljøet grundet bygning og brug af idrætsfaciliteter (opvarmning, belysning, rengøring, bad), transport, vask samt brug af tøj og udstyr. Alt i alt et $\varnothing$ get brug af det generelle ressourceforbrug og en $\varnothing$ get miljøbelastning.

Forståelsen af, hvad der er miljøproblemer, og hvorledes de kan løses, har ændret sig betydeligt siden 1970'erne. Der er i dag en større erkendelse af miljøproblemernes sammenhæng og kompleksitet, og nødvendigheden af at tænke $\mathrm{i}$ helheder, når der skal findes løsninger på problemerne. Det betyder, at det er nødvendigt at medtage miljøpåvirkningerne fra produktet i hele dets livscyklus lige fra udvinding af ressourcer over produktion af materialer til brug og endelig bortskaffelse af produktet. Der er blevet langt større fokus på det forebyggende miljøarbejde, der bevidst sigter på at begrænse ressourceforbruget $\mathrm{og}$ at forbedre virksomhedens påvirkning af det ydre miljø, så tæt ved kilden som muligt.

Ved vurdering af idrættens miljøbelastning skal der principielt anlægges et globalt perspektiv og foretages en vurdering af det enkelte produkt set i et livscyklusperspektiv.

Idrætsoplevelsen kan betragtes som en produktkæde bestående af en række forskellige produkter, hvor hvert produkt er nødvendigt for aktiviteten og bidrager til den samlede miljøbelastning, og hvor der er mulighed for udvikling af bæredygtige løsninger både samlet set og inden for hvert produktområde:

Udstyr og tøj - Transport - Idrætsfaciliteter

Når det gælder idrætsbyggeri vil både selve bygningen og placeringen af denne i forhold til transport have stor betydning for miljøbelastningen. Tøj og udstyr vil ikke blive behandlet nærmere her, da belastningen ikke direkte er påvirket af byggeriet.

\section{Idratsfaciliteter}

Ud fra en miljømæssig betragtning kan motions- og idrætsaktiviteterne opdeles således:

- Aktiviteter, der er uafhængige af større faste anlæg - f.eks. jogging

- Aktiviteter, der er tilknyttet en idrætshal eller -anlæg - f.eks. fodbold

Det betyder ikke, at idrætsaktiviteter, der foregår i det fri, altid er miljøvenlige, men en måde at separere de idrætsgrene, hvor byggeriet indgår som en væsentlig faktor. Ethvert bygge- og anlægsprojekt vil resultere i miljøpåvirkninger relateret til energiforbrug, ressourceforbrug i $\varnothing$ vrigt, milj $\varnothing-$ og sundhedsfarlige stoffer, indeklima og arbejdsmiljø.

Byggeri generelt er på flere måder en af de mest miljøbelastende aktiviteter i det danske samfund. Ca. 50\% af energiforbruget stammer fra etablering og drift af bygninger ${ }^{10}$, og der anvendes store mængder af materialer, herunder miljøfremmede stoffer i byggesektoren. Ca. $27 \%$ af affaldsproduktionen eller godt 3 mio. tons affald pr. år stammer fra byggeriet som helhed. ${ }^{11}$ Hvor stor en andel, der hidrører fra idrætsbyggeriet, kendes ikke. 


\section{Transport}

Udover selve bygningen har transporten frem og tilbage fra idrætshallen betydning for ressourceforbrug og forurening. Miljømæssigt set er det stigende forbrug af transport et af de vigtigste miljømæssige og $\varnothing$ konomiske udfordringer i Danmark. ${ }^{12}$

Kørsel i fritiden udgør en stadig stigende andel af familiens tilbagelagte kilometer i bil. I transportvaneunders $\emptyset$ gelsen fra 1999 udgør tur-formålene »bolig-fritid « og »andet« tilsammen $59 \%$ af den samlede persontransport. ${ }^{13}$ Der kan samtidig konstateres en stigning i både antal og brug af biler, men det vides ikke hvor stor en andel, der skyldes motion og idrætsoplevelser.

Derfor er forhold som infrastruktur, den fysiske placering af idrætsfaciliteter, mulighederne for offentlig transport, sikre cykelveje etc. alle eksempler på elementer, der har indflydelse på transportbehov og valg af transportmiddel.

\section{Eksempler på miljørigtigt idratsbyggeri}

I Danmark findes ikke mange eksempler på, at miljøhensyn er tænkt ind allerede ved planlægning af et idrætsbyggeri. Det er lykkedes at finde tre konkrete eksempler på foreninger, der har gennemført denne proces, og disse er suppleret med et par internationale eksempler.

\section{Udbygning af klubhus}

Stillinge Idrætsforenings klubhus havde intet bad, og der var ingen mulighed for at samles efter endt træning. I 1998 tog klubbens formand derfor initiativ til en udvidelse af klubhuset og til at få indlagt vand. ${ }^{14}$ Han kontaktede en konsulent fra DGI Sorø amt for at få hjælp til byggeriet og blev henvist til den Grønne Guide i kommunen. Det endte med at blive et miljørigtigt byggeri. Tilbygningen blev lavet af lærketræ, så man undgik brug af trykimprægnering. Endvidere benyttedes Pvcfri kloakrør, isolering med genbrugspapir i stedet for stenuld, opsætning af vandsparetoiletter og -brusere, udskiftning af elvarme med naturgas, og der blev sat en solfanger på taget.

Projektet blev støttet med midler fra Lokale- og Anlægsfonden, Elsparefonden og Slagelse Kommune. Det blev som udgangspunkt over dobbelt så dyrt at bygge miljørigtigt i forhold til at bygge et helt almindeligt klubhus, men det vil tjene sig ind i den efterfølgende driftsfase. Den store investering til naturgas vil f.eks. tjene sig ind i løbet af en 5-årig periode, og så har man både en billigere og samtidig en mindre ressourcekrævende og forurenende varme end el-varme.

Blandt håndværkerne, der f.eks. udførte rørarbejdet, var der ikke den store forståelse for de grønne ideer. Mange af håndværkerne vidste ikke, at man kunne få pvc-fri rør, og det var først efterhånden, som byggeriet skred frem, at håndværkerne kunne se, at det var en god ide med det grønne byggeri. Idrætsforeningens medlemmer har været inddraget i processen og ydet en stor indsats i forbindelse med klubbyggeriet, hvilket samtidig har betydet, at byggeriet har taget længere tid.

Stillinge IF valgte at bygge på denne måde for at få et sundt klubhus og for at vise ungdomsmedlemmerne vejen frem, når det gælder miljøet. Idrætsforeningen fik i 1998 tildelt Danske Gymnastik- og Idrætsforeningers Grønne Pris. ${ }^{15}$ 


\section{Etablering af nyt klubhus}

Jetsmark Idrætsforening havde et $45 \mathrm{~m}^{2}$ stort rum til de 500 medlemmer i fodboldklubben, hvilket ikke var særlig befordrende for det sociale samvær. Med bygning af et nyt klubhus blev der for alvor plads til at udvikle de sociale sider af foreningen. ${ }^{16}$ Idrætsforeningen vil samtidig gerne bidrage til, at medlemmernes børn og børnebørn får gode forhold at vokse op i og valgte derfor at bygge miljøvenligt.

Det nye $450 \mathrm{~m}^{2}$ store klubhus er i to etager. Klubhuset har alle faciliteter - lige fra elevator til panorama-udsigt over stadion og de bagvedliggende marker. Der er ved opførelsen taget væsentlige hensyn til valg af miljøvenlige materialer som f.eks. træ, der anvendes til gulv og beklædning.

Ifølge formanden var det ikke en større kraftanstrengelse at bygge et miljørigtigt klubhus, fordi det hele blev tænkt igennem, og der blev lavet en detaljeret projektbeskrivelse. Eksempelvis var der anvisninger på, hvordan de elektriske installationer blev mest miljøvenlige. Der spares på varmen ved at lægge varmen i gulvet og ved at gøre isoleringen dobbelt. Et anlæg skifter luften ud, men beholder varmen, som bliver brugt igen, samtidig udnyttes solvarmen, som leveres gennem de store vinduespartier.

En lokal arkitekt tegnede huset, en rådgivende ingeniør tænkte miljørigtige materialer ind i huset, og der er gjort brug af lokale leverandører. I dag er der ansat en »grøn « klubhusbestyrer, der skal sikre, at der også bliver taget hensyn til miljøet f.eks. ved at spare på vand og varme ved driften af klubben.

Projektet blev finansieret af Pandrup Kommune, Lokale- og Anlægsfonden, lokale sponsorer og indtægter fra idrætsforeningens aktiviteter.
Jetsmark Idrætsforening modtog juli 2000 DGIs Grønne Pris for at være den første forening, der ansatte en grøn klubhusbestyrer, ligesom der ved opførelsen er taget væsentlige hensyn til materialevalg og brug af lokale leverandører. ${ }^{17}$

\section{Tennishal af halm}

Humlum Tennisklub ved Struer er den første klub herhjemme, som opfører en tennishal af halmballer (de såkaldte bigballer). ${ }^{18}$ Halmhallen kommer til at rumme en tennisbane og er placeret på en $1.000 \mathrm{~m}^{2}$ stor grund tæt på tennisklubbens to udendørsbaner. Halmballerne beklædes med trådnet og pudses. Over halmen lægges et tag, som kan skydes til side om sommeren. Dermed skabes en isolerende ramme for indendørs grustennis, der tilgodeser de mest basale behov. Banen bliver gravet en meter ned, hvilket sammen med de tykke halmmure formentlig gør den frostfri under en normal vinter.

Halmhallen indgår i Lokale- og Anlægsfondens udviklingsarbejde og sigter på at vise, at der for et forholdsvis beskedent beløb kan etableres udfoldelsesmuligheder, der svarer til faciliteterne i en almindelig idrætshal og er et eksempel på anvendelse af alternative miljøvenlige materialer. ${ }^{19}$ Byggeriet er finansieret via et lån fra DGI's lånefond og etableringsstøtte fra Lokale- og Anlægsfonden.

\section{Passivhaus}

Siden 1992 har der primært i Tyskland og Østrig været udvikling af passiv hus byggeriet især inden for enfamilieboliger, men nu er konceptet også blevet anvendt ved bygning af en sportshal. Konceptet går ud på at bygge huse, der opvarmer og afkøler sig selv, heraf ordet »passivt« hus. Her er 


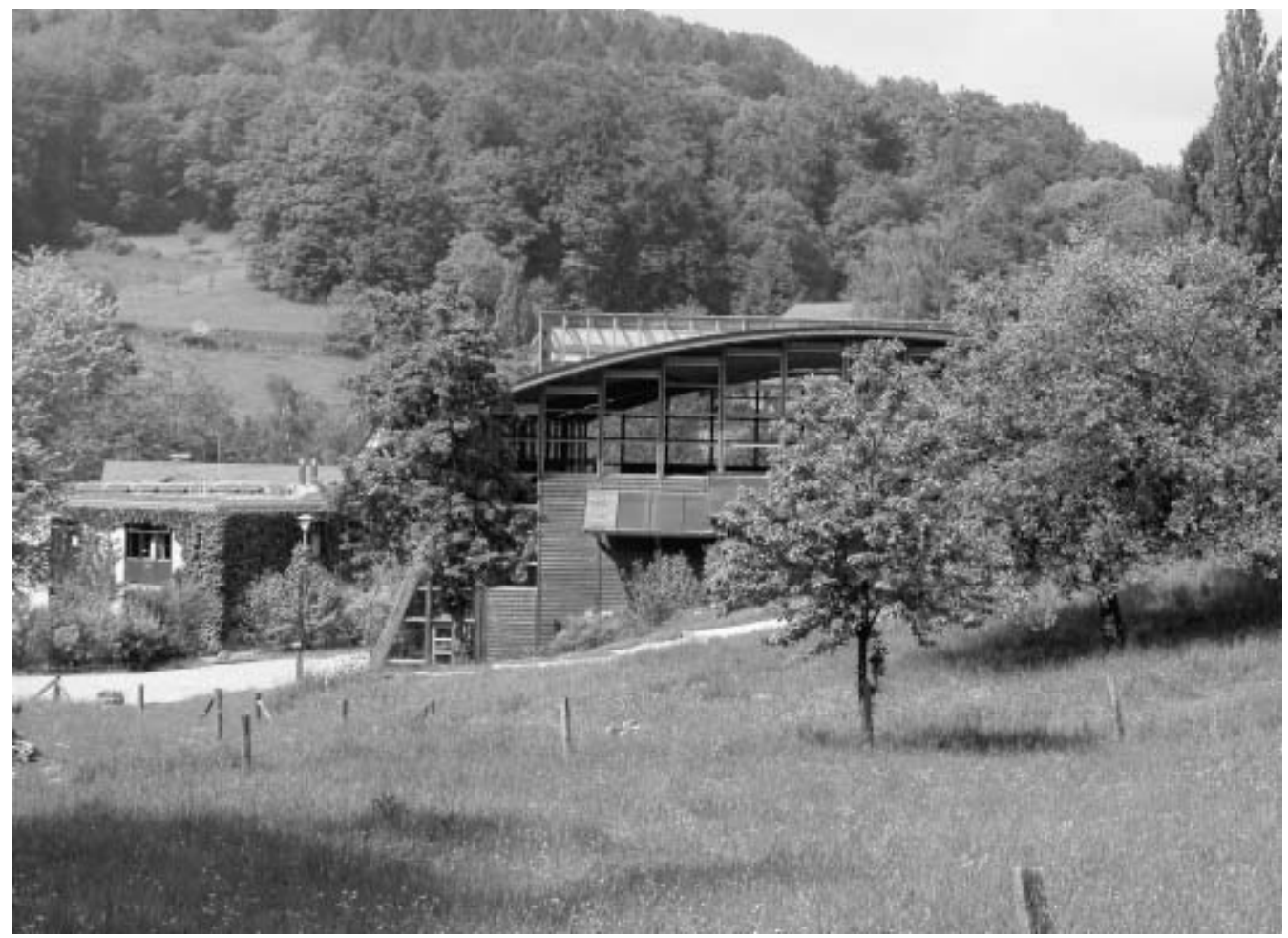

Byen Heidelberg, der har fungeret som bygherre på projektet, har siden 1992 arbejdet for at få implementeret lav-energi standarder i forbindelse med saneringsprojekter og nybyggeri. Dette er et centralt element for at kunne leve op til målene i deres klimabeskyttelsesprogram.

varmegenindvinding, et højt isoleringsniveau uden kuldebroer og huse med en stor tæthed. Resultatet er huse, der opvarmes uden tilførsel af varme, og huse med et energiforbrug på kun $15 \mathrm{kWh} / \mathrm{m}^{2}$. Til sammenligning har et almindeligt parcelhus et forbrug på $113 \mathrm{kWh} / \mathrm{m}^{2}$, et lavnergihus 57 $\mathrm{kWh} / \mathrm{m}^{2}$, og de nye krav i Bygningsreglementet for 2005 lægger op til et energiforbrug på $76 \mathrm{kWh} / \mathrm{m}^{2} .^{20}$

I byen Heidelberg i Tyskland er disse principper blevet anvendt $\mathrm{i}$ forbindelse med opførelsen af en sportshal til skolens elever. ${ }^{21}$ I samarbejde med Passivhaus Instituttet er konceptet blevet tilpasset sportshaller frem for villaer. Her er bl.a. anvendt sydvendte glasfacader til udnyttelse af solvarme, en lufttæt konstruktion uden kuldebroer, god isolering af bygningen samt et udluftningssystem, der effektivt udnytter varmen i luften om vinteren og afkøler den om sommeren.

\section{De Olympiske Lege}

OL i Lillehammer 1994 var det første store idrætsarrangement, hvor arrangørerne for alvor prioriterede miljøet og tænkte på følgerne. Under planlægningen af OL i Lillehammer 1994, blev miljøet og naturen for første gang sat i fokus. Grunden til dette fokus var, at arrangørerne havde set og lært 
af tidligere OL arrangementer, hvor forureningen og miljøbelastningen var stor på grund af alle aktiviteterne $\mathrm{i}$ forbindelse med legene. ${ }^{22}$

Gennem følgende mål skulle miljøprofilen sikres:

- Skabe miljøbevidste holdninger.

- Varetage regionale samfundshensyn.

- Fremme bæredygtig udvikling og vækst.

- Miljøvenlig udbygning af anlæg.

- Kræve miljøkvalitet i alle led under arrangementet.

Hamar Olympiahal fik arkitekturen tilpasset miljø og tradition og byggede på ideen om en hvælvet båd fra Mjøsen-området. Stedspecifikke materialer, så som træ og sten, blev brugt i størst mulig grad som materiale på arenaerne. Energieffektive løsninger, der var omkostningsbesparende i drift med hensyn til opvarmning og nedkøling, blev valgt, og miljørevision blev gennemført som en del af kvalitetssikringen på fire af de største anlæg.

I OL i Sydney 2000 blev også taget gennemgribende hensyn til miljøet. Norge og Australien fik meget omtale i pressen om de forskellige miljøtiltag og beskrivelsen af nye teknologiske landvindinger på miljøområdet. Det efterlader et positivt indtryk af to lande, der er i stand til at planlægge meget store arrangementer og samtidig udvise ansvarlighed og hensyn til natur, miljø og mennesker.

Ved OL i Athen forholder det sig anderledes. I den græske ansøgning om værtsskabet blev der lagt vægt på at gennemføre visionære og konkrete miljøtiltag, men mange af disse blev ikke blevet gennemført i praksis. Dette er bl.a. blevet kritiseret af Greenpeace, der i en rapport peger på, at årsagen hverken er mangel på teknologisk viden, eller at det skulle blive dyrere at gennemføre, men at hverken den græske regering eller organisationskomiteen har haft den nødvendige politiske vilje til at gøre legene til et bæredygtigt arrangement. ${ }^{23}$

Greenpeace har allerede i 2000 udarbejdet retningslinier for bæredygtig planlægning og afholdelse af OL målrettet de byer og lande, der skal afholde de Olympiske Lege. ${ }^{24}$

\section{Miljøvenlig drift af idratshaller og -anlacg}

Udover at inddrage miljøaspektet ved anlæg af nye idrætsfaciliteter er der en lang række muligheder for at tage miljøhensyn i det eksisterende byggeri. Da en betydelig del af både miljøbelastningen og de økonomiske omkostninger ved et idrætsbyggeri ligger i driftsfasen, er det derfor relevant at nævne de muligheder, som idrætsforeningerne har for at agere miljøvenligt i driftsfasen.

\section{Den Grønne Nфgle}

Til fremme af mere miljøvenlig drift kan idrætsanlæg ansøge om at blive Grøn Nøgle virksomhed..$^{25}$ For at opnå miljømærket skal virksomheden opfylde en række specifikke krav om f.eks. anvendelse af miljømærkede og $\varnothing$ kologiske produkter, inddragelse af leverandører, begrænsning af eget el-, vand- og varmeforbrug etc. Desuden skal virksomheden udarbejde en miljøpolitik og fastsætte langsigtede mål for miljøarbejdet. Der er særlige kriterier for henholdsvis haller med boldspil, svømmehaller, ishaller og udendørs anlæg.

De to første idrætsanlæg blev tildelt Den Grønne Nøgle i 2000, og i dag har ni idrætshaller/-anlæg denne miljømærkning: 
Glostrup Idrætspark, Glostrup Idrætscenter, IS Vestbad, Næstved Hallerne, Taastrup Svømmehal, Virum Hallerne, Hvissingehallen, Slotsøbadet og Sydthy Svømmebad. Halinspektørforeningen har en målsætning om, at 25 idrætshaller bliver miljømærket inden udgangen af 2005. ${ }^{26}$

Det er frivilligt at medvirke i mærkningsordningen, og alle virksomheder med Den Grønne Nøgle kontrolleres én gang årligt. Bag den Grønne Nøgle står bl.a. Miljøstyrelsen, Friluftsrådet, turismens organisationer og Halinspektørforeningen.

\section{Miljøledelse}

Udgangspunktet for idrætsforeninger og -virksomheders arbejde med miljøledelse er, at der foretages en miljøgennemgang. Denne udarbejdes ofte på basis af checklister og manualer. Ved opbygning af et miljøledelsessystem formuleres miljøpolitik-

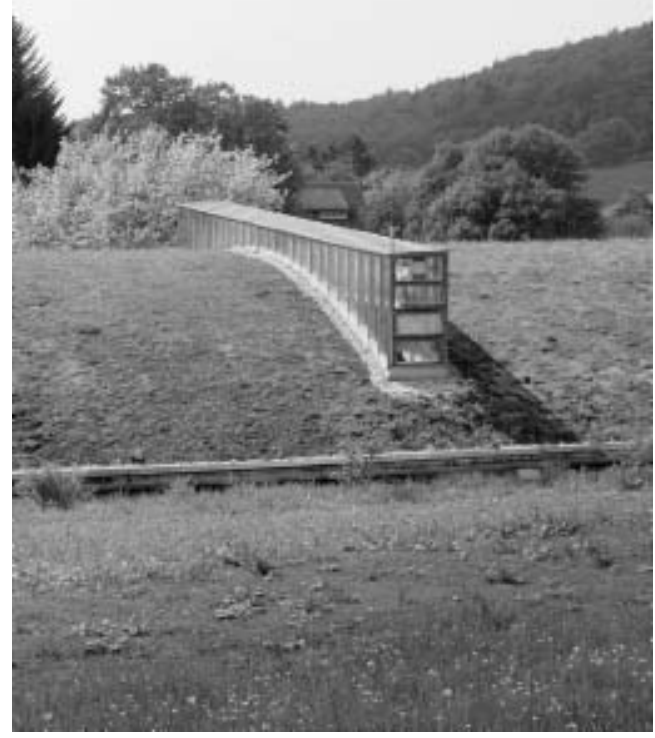

Her ses taget på en sportshal i den tyske by Heidelberg. ker, målsætninger og handlingsplaner, og udviklingen følges op i en miljøredegørelse, hvor dokumentation for årets resultater fremgår.

Man kan have både små og store ambitioner på miljøområdet. Flere idrætsforbund, f.eks. sejlsport og golf, har udarbejdet håndbøger til hjælp for dette arbejde ude $\mathrm{i}$ foreningerne, og nogle sportsgrene har internationale miljømærkningsordninger som f.eks. Committed to Green. ${ }^{27}$

En række lystbådehavne har valgt at være medlem af Green Network, der er et regionalt samarbejde om bæredygtighed med særlig fokus på miljø og social ansvarlighed mellem private virksomheder og offentlige myndigheder i Vejle Amt. ${ }^{28} \mathrm{Om}$ drejningspunktet for samarbejdet er virksomhedernes frivillige udarbejdelse af miljøredegørelser

Det er muligt få sit miljøledelsessystem certificeret efter en af de 2 internationale standarder for miljøledelse ISO14001 og EMAS. ${ }^{29}$ Standarderne kræver, at en virksomhed definerer sine miljømæssige målsætninger og har et ledelsessystem til at opnå disse mål. Standarden kræver desuden, at virksomheden holder fast ved systemets processer, procedurer og aktiviteter. Albertslund Svømme- og Idrætsanlæg er et eksempel på, at også idrætsanlæg er EMAS registreret.

Dokumentation af idrætsanlæggenes miljøbelastning kan også ske ved at udarbejde et årligt grønt regnskab, der gør rede for forbruget af f.eks. el, varme og vand samt brug af rengøringsmidler og kemikalier. På denne måde er det muligt at følge udviklingen fra år til år, og at dokumentere om en given miljøindsats har medført en $\emptyset n s k e t$ virkning. Flere idrætsforeninger udarbejder årligt grønne regnskaber. 


\section{Idrattens organisationer}

Idræt i Danmark er i vid udstrækning et anliggende for det frivillige foreningsliv, og det anslås, at ca. 2 mio. danskere dyrker idræt $\mathrm{i}$ en af landets ca. 14.000 idrætsforeninger. ${ }^{30}$

I den enkelte klub vil det ofte være bestyrelsesmedlemmer eller andre ildsjæle med særlig interesse for miljøforhold, der har betydning for, om et byggeri bliver miljøvenligt eller ej. Idrætsforeningers arbejde med miljøvenligt anlæg og drift af idrætsbyggeri kræver både visioner, viden og værktøjer for, at processen kan gennemføres i praksis.

Ganske få idrætsforeninger og -forbund har medarbejdere eller frivillige til at tage sig af miljøspørgsmål vedr. idrætsbyggeri, og der findes ikke nødvendigvis specialviden på dette område.

\section{Danmark Idraets-Forbund}

DIF har indarbejdet miljø i sit overordnede politiske program. ${ }^{31}$ Af programmet fremgår, at forbundet på miljø- og planlægningsområdet bl.a. arbejder for at sikre optimal udnyttelse af Århus-Konventionen (borgerinddragelse), at $\emptyset$ ge den enkelte udøvers miljøbevidsthed og at sikre udbygning af anlæg i, hvad DIF definerer som idrætsligt dårligt stillede områder.

Forbundet rådgiver om miljøforhold og fysisk planlægning, men der ydes ikke direkte rådgivning til foreninger eller kommuner, der $\varnothing$ nsker at inddrage miljøhensyn i idrætsbyggeriet. Ifølge miljøkonsulent Dorthe O. Andersen får DIF ofte henvendelser fra foreninger, der vil have mere at vide om miljøhensyn i byggeriet ${ }^{32}$, og forbundet er derfor i gang med at udarbejde et lille hæfte med beskrivelse af, hvorledes man kan gå frem, hvis klubben ønsker at gennemføre et projekt med miljørigtigt byggeri. ${ }^{33} \mathrm{Hensig}$ ten er at give bygherrer et værkt $\varnothing j$-en metode - som kan bruges systematisk allerede tidligt i projektet i bygherrens dialog med myndigheder, arkitekter, ingeniører, idrætsinspektører og andre fagfolk. Pjecen offentliggøres i løbet af efteråret 2004.

DIF uddeler årligt en miljøpris til den eller dem, der har været særlig på spring for idrætten og miljøet. ${ }^{34}$ I forbindelse med kritikken af det manglende miljøhensyn ved afholdelsen af OL 2004 i Athen udtaler DIFs Informationschef Morten Mølholm Hansen til DR1, at atleterne er fokuseret på, at tingene fungerer, og ikke på, at miljøet er i orden.$^{35}$ Dette tyder på, at forbundets miljøpolitik ikke er implementeret i hele organisationen.

\section{Danske Gymnastik og Idratsforeninger (DGI)}

DGI havde tidligere en miljøkonsulent til at rådgive på miljøområdet. I dag yder DGI ingen rådgivning på miljøområdet og betragter hensyn til miljøet som implementeret og ansvaret placeret hos hver af de 5000 medlemsforeninger. ${ }^{36}$ Tidligere var der flere grønne guider ansat i DGIs lokalforeninger til at underst $\varnothing$ tte det lokale arbejde, men med lukning af Den Grønne Fond 2001 forsvandt medfinansieringen og dermed grundlaget for ansættelsen. ${ }^{37}$

DGI rådgiver i forbindelse med byggeri, men har ingen nedskrevet miljøpolitik eller målsætninger på miljøområdet. Tidligere havde DGI en grøn pris, der blev uddelt en gang årligt med det formål at synliggøre miljørigtige eksempler indenfor idrætten. ${ }^{38}$ Denne pris uddeles ikke længere.

Til anlæggelse af lokale idrætsfaciliteter og indk $ø$ b af rekvisitter i år yder DGI både lån og tilskud. I 2003 var den årlige udde- 
ling fra organisationens lånefond og tilskudspulje for rentefrie lån på 6.590 .000 kroner og tilskud på 1.388 .000 kroner. $^{39}$ Der stilles ingen miljøkrav i forbindelse med lån og tilskud fra disse puljer.

\section{Team Danmark}

Team Danmarks planafdeling yder rådgivning til idrætsbyggeri inden for planlægning, udførelse, renovering og ombygning af sportsbyggeri. Team Danmark har ingen overordnet miljøpolitik, men planlægningschef Birger Kyhl fortæller, at man altid opfordrer bygherrer til at tænke på natur- og oliemaling, på alternative energimuligheder og genanvendelige materialer. Han gør samtidig opmærksom på, at det er en meget konservativ branche, der først og fremmest fokuserer på $\varnothing$ konomi, funktionalitet og omklædningsfaciliteter, og når man til sidst kommer til de andre ting som f.eks. miljøet, så er pengene brugt « ${ }^{40}{ }^{0}$

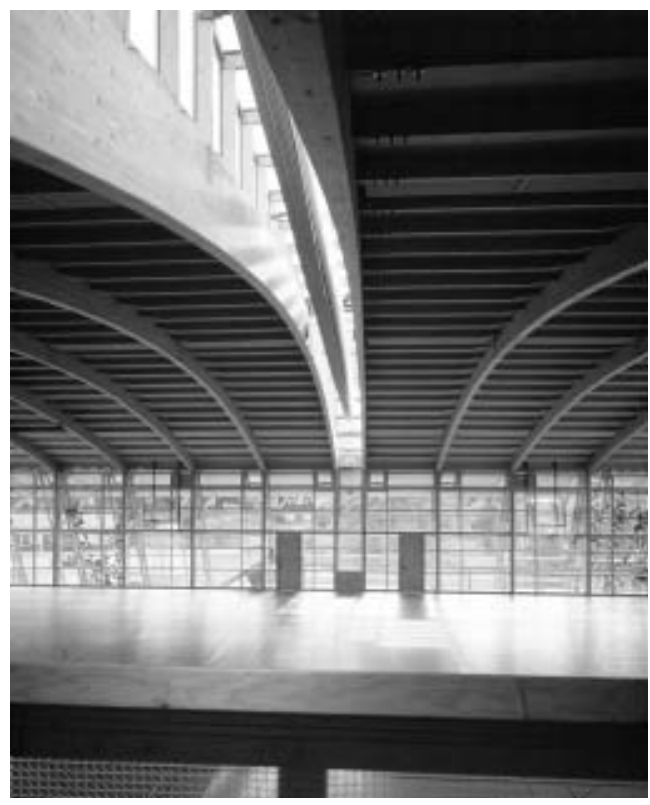

Interior i sportshallen i den tyske by Heidelberg.

\section{Lokale- og Anlagsfonden (LOA-Fonden)}

Udfra devisen om, at det er en god ide at bygge miljøvenligt, udgav Lokale og Anlægsfonden i 1998 en pjece om miljørigtigt byggeri - et praktisk inspirationsredskab for foreninger, der havde besluttet at tage hensyn til miljøet ved bygning af et klubhus eller udendørs anlæg. ${ }^{41}$ Pjecen publiceres ikke længere. Ifølge konsulent Holger Kortbæk, LOA-Fonden er den forældet, og der er ingen planer om at udarbejde en ny, da miljøforhold i dag er blevet en integreret del af byggeriet. ${ }^{42}$ I stedet skal projektansøgere gøre rede for miljøhensyn ved ansøgning til fonden. Der er ingen konkrete mindstekrav til de miljøforhold, der skal opfyldes ved ansøgningerne.

Miljø indgår ikke i Fondens overordnede strategi ${ }^{43}$, men der er udarbejdet en miljøpolitik, der for tiden er under revision og vil blive offentliggjort senere på året.

LOA-Fondens formål er at støtte byggeri inden for kultur- og fritidsområdet. Fonden st $\varnothing$ tter hvert år byggeri og anlæg for 100 mio. kr., hvilket svarer til at der bliver bygget for over $400 \mathrm{mio}$. kr. bygninger. Ifølge fondens egne formålsparagraffer skal støtten baseres på spørgsmålet om kvalitet, hvor støtte gives til projekter, der er arkitektonisk nyskabende, tager et overordnet miljø- og planlægningsmæssigt hensyn og tager udgangspunkt i den frivillige indsats, og som hviler på brugerindflydelse og -styring.

Lokale- og Anlægsfonden blev etableret i 1994 og har en egenkapital på 140 mio. kr., indskudt af Danmarks Idræts-Forbund, Danske Gymnastik- og Idrætsforeninger, Dansk Firmaidrætsforbund og Dansk Ungdoms Fællesråd. Fonden modtager årligt ca. 65 mio. kr. af tips- og lottomidlerne. 


\section{Den internationale olympiske komite (IOC)}

I 1995 blev bæredygtig udvikling og miljøhensyn en af de 3 søjler i olympismen på linie med sport og kultur. I 1996 vedtog IOC en Agenda 21 plan, hvor det blev slået fast: At de olympiske lege ikke alene skal afvikles uden negative konsekvenser for miljøet, men også forbedre miljøet og efterlade en positiv arv efter legene. ${ }^{44}$

Det er i dag et krav til alle byer, der byder ind til værtsskabet for de olympiske lege, at de skal beskrive, hvordan de vil opfylde miljømålsætningen. Men det er op til den enkelte værtsby at efterleve den olympiske miljøvision, og der er ingen mindstekrav på området.

\section{FIFA World Cup 2006}

I forbindelse med Tysklands kommende afholdelse af verdensmesterskabet i fodbold 2006 har det internationale fodboldforbund FIFA udarbejdet Green Goal - Environmental goals for the 2006 FIFA World Cup. ${ }^{45}$ Præsidenten for organisationskomiteen Franz Beckenbauer og det tyske fodboldforbund har erkendt, at dette er en oplagt chance og en stor mulighed for at præsentere værtslandet Tyskland som både gæstfrit, meget interesseret i sport og samtidig bevidst om sit ansvar over for natur og miljø.

Green Goal er det første miljøkoncept for en større international sportsbegivenhed, hvor der bliver opstillet kvantifiserbare miljømål for gennemførelse af arrangementet. Der er f.eks. udarbejdet konkrete mål for energiforbrug, vandforbrug, affald og mobilitet (transport og logistik). De byer og stadions, der konkurrerer om at få lov til at afholde arrangementet bliver bl.a. bedømt på, om de kan leve op til de stillede miljøkrav.
Implementeringen af miljøkonceptet er samtidig en integreret del af planlægningen og kommunikationen med omverdenen, hvor »Sport and sustainability go hand in hand « bliver et centralt tema allerede i perioden op til verdensmesterskabet 2006.

\section{Hvem har ansvaret?}

At starte et byggeprojekt er en større proces, der involverer mange aktører. Fokus er ofte rettet mod de funktionelle krav, hvilket betyder, at hensynet til miljøet i mange tilfælde først kommer på banen, når det reelt er for sent at ændre ret meget på projektet.

De beskrevne eksempler på miljørigtigt idrætsbyggeri bygger i høj grad på efterspørgsel og motivation fra den enkelte idrætsforening og er baseret på frivillige initiativer og ordninger. Men idrætsorganisationerne er ikke de eneste aktører ved bygning af nye idrætsfaciliteter, også kommunerne har en central rolle lige som arkitekter og rådgivende ingeniører.

\section{Myndighederne}

Til at understøtte en bæredygtig udvikling af byggeriet findes en række reguleringer og virkemidler inden for det offentlige, som kan få betydning for den fremtidige udvikling af det miljørigtige idrætsbyggeri, hvoraf nogle af disse er beskrevet.

Sammenfattende kan man sige, at bæredygtig udvikling inden for idrætsbyggeri betyder, at kvalitet, $\varnothing$ konomi, miljø og sociale forhold integreres ved den overordnede planlægning og gennemførelse af idrætsbyggeriet - både ved anlæg og drift. 


\section{Kommunerne}

Kommunerne spiller en vigtig rolle for udviklingen i byggeri og byplanlægning, idet de agerer som både planlægger, bygherre og myndighed - også når det gælder idrætsbyggeri. Anvisninger til miljøvenligt byggeri kan bl.a. indgå på forskellig vis $\mathrm{i}$ kommuneplaner, lokalplaner, Agenda 21strategier, servitutter og bygherrevejledninger.

Kommuneplanen kan anvendes som et aktivt styringsmiddel for indsatsen for bæredygtig udvikling. Flere kommuner har udarbejdet vejledninger, der har til formål at illustrere miljøkravene med vellykkede eksempler på, hvordan miljøhensyn kan integreres i både ældre og nyt byggeri og således være med til at skabe god og oplevelsesrig arkitektur, som er indpasset stedets særlige kvaliteter. ${ }^{46}$ Der er også eksempler på konkrete standarder for miljørigtig projektering med minimumskrav, der skal følges i forbindelse med byfornyelse, støttet byggeri, og når kommunen selv er bygherre. ${ }^{47}$

Ifølge planloven kan kommunerne ikke stille krav om bæredygtigt byggeri i lokalplanens bestemmelser, så de er juridisk bindende. ${ }^{48}$ Den eneste mulighed for at skærpe kravene til bæredygtighed i bygningsmassen er, hvis kommunerne ejer og sælger den jord, hvorpå der skal bygges. ${ }^{49} \mathrm{I}$ Glostrup Kommune opføres i øjeblikket ca. 200 boliger som $» \varnothing$ kologisk byggeri $\ll$, og her blev $\emptyset$ kologien sikret gennem salgsmaterialet for grunden og ved tinglysning på området. ${ }^{50}$

Planloven pålægger amter og kommuner at udarbejde en strategi for deres bidrag til en bæredygtig udvikling i det 21. århundrede (Lokal Agenda 21).$^{51}$ Strategien skal indeholde målsætninger for 5 indsatsområder, hvoraf 2 er relevante for byggeriet heriblandt - at fremme bæredygtig byudvikling og byomdannelse - at mindske miljøbelastningen.

Kommunerne kan bruge Agenda 21 strategier til at stille krav om miljø i de offentlige byggeprojekter. Flere kommuner har benyttet lejligheden til at stille konkrete krav om miljøvenlige materialer og lavenergi til offentligt støttet byggeri og strategier, der kan underst $\varnothing t t e$ udviklingen af bæredygtigt byggeri. ${ }^{52}$

Der er mange flere eksempler og Dansk Center for Byøkologi har en mere fyldestgørende oversigt over de forskellige kommunale strategier og vejledninger på deres hjemmeside. ${ }^{53}$

\section{Staten}

De nationale udviklingsprogrammer har primært haft det private by- og boligbyggeri som indsatsområde, men nye krav fra EU stiller skærpede krav til bygningers energimæssige ydeevne. ${ }^{54}$ For at leve op til det nye EU-direktiv skal Danmark i de fremtidige energibestemmelser i Bygningsreglementet opstiller mindstekrav til en bygnings energimæssige ydeevne. Det nye er, at energikravet ikke blot omfatter bygningens varmeisolering, men også en række andre forhold, bl.a. klimaanlæg, belysning og vedvarende energi; forhold som spiller en stigende rolle for bygningers energibalance.

Af Energistyrelsens energipolitiske redegørelse fremgår, at den danske regering har sat som mål, at der skal ske en stramning af energikravene i Bygningsreglementet med 25-30 pct. for nye bygninger. ${ }^{55}$ Men også kravene til eksisterende bygninger skal skærpes for at opnå betydelige besparelser ved ombygning og renovering. 


\section{Bygherre og rådgivere}

Bygherre kan stille miljøkrav og efterspørge miljøvenlige materialer, konstruktioner og drift. For idrætsbyggeri vil det ofte være kommunen, idrætsklubben eller - foreningen, som er bygherre, og som stiller krav. Nogle kommuner har udarbejdet retningslinier for, hvorledes miljøhensyn kan inddrages i byggeriet, hvilket kan være en stor hjælp, da det kræver viden at stille disse krav.

Samarbejdet med rådgiverne f.eks. arkitekter, ingeniører, deres holdning til miljøhensyn og viden på området har også stor betydning for resultatet. Et af problemerne er, at det ikke er så almindeligt at integrere miljø i alle byggeprojektets faser.

Ved miljøvenlig projektering af byggeri opstiller man en række miljømål for de væsentligste miljøbelastninger fra byggeriets i dets anlægs- og driftsfase. Hvis de opfyldes, vil det betyde at miljøbelastningen for det aktuelle byggeri begrænses. ${ }^{56}$ Det svære er at vurdere, om man har valgt de rigtige mål. ${ }^{57}$

Ofte opfattes miljøhensyn som en »ekstra « foranstaltning, der ligger ud over, hvad der er nødvendigt. Det er optimalt, hvis miljøhensyn kan indgå som en del af bygningens samlede kvalitet. Det kræver, at forbedret indeklima, energieffektivitet m.m. opleves som lige så vigtige som andre parametre. Kun på den måde kan det sikres, at disse ting ikke opleves som en ekstra investering, der belaster byggeprojektets $\varnothing$ konomi udover en fastsat ramme.

Akademisk Arkitektforening har udarbejdet en miljøpolitik med en målsætning om, at arkitekternes arbejde med miljørigtige løsninger skal være indiskutabel »standard $\ll .{ }^{58}$ Det er almindelig standard i konkurrencer og byggeprogrammer at skri- ve, at der skal tages miljømæssige eller bæredygtighedshensyn ved udformningen af byggerier, men der findes ikke mange projekter med høj arkitektonisk kvalitet, som samtidig er gennemgribende miljøsikret. At integrere miljøhensyn og at dokumentere dette er ikke så almindeligt, og ofte har miljøindsatsen været en række teknologiske løsninger, som er tilføjet et traditionelt byggeri. ${ }^{59}$

I starten af 2004 blev resultaterne af Danmarks første internationale arkitektkonkurrence om moderne, miljørigtigt byggeri offentliggjort. Det var første gang, at en bygherre opstillede målbare miljøkrav til byggeriet. Projektforslagene viste, at tegnestuerne i dag er i stand til at kombinere god arkitektur og miljø- og energibevidst byggeri. ${ }^{60} \mathrm{I}$ vinderprojektets forslag er energiforbruget i den ene boliggruppe således helt nede på $15 \mathrm{kWh} / \mathrm{m} 2 / a ̊ r$, det samme som Passivhaus standarden. ${ }^{61}$

Meget kan gøres allerede nu ved at undgå kuldebroer, at højisolere, at sørge for tætheden og at vælge A-klassificerede vinduer, og der burde udarbejdes en række ydeevnekrav, så arkitekter og ingeniører ved, hvad de skal leve op til f.eks. et energiforbrug på $25 \%$ af bygningsreglementet. ${ }^{62}$ Ydeevnekravet har ydermere den fordel, at det fastholder arkitektens kreative frihed og udfordrer ingeniøren til at finde de optimale løsninger.

Det kan lade sig gøre i udlandet, men ifølge Akademisk Arkitektforening bliver den miljørigtige løsning ofte valgt fra, fordi rådgiveren er alt for dårligt klædt på til at kunne besvare bygherrens mange spørgsmål, og resultatet bliver ofte, at valget derfor falder på det kendte. ${ }^{63}$ Der har tidligere været en opfattelse af, at miljørigtig projektering er et arbejdsområde for specialister (ingeniører), men arkitekterne 
vil gerne gøre det til en disciplin, der kan integreres i almen praksis. ${ }^{64}$

Der ser ud til at være behov for fælles mål, bedre koordinering og samarbejde i byggebranchen. Det var også en af konklusionerne, som »Byggepanelet«, der blev nedsat af Miljøstyrelsen i 2000 nåede frem til i sin handlingsplan for bæredygtig udvikling i dansk byggeri. ${ }^{65}$ Der peges i handlingsplanen på nødvendigheden af, at regeringen styrker indsatsen for at integrere miljøhensyn i byggeriet, og at alle byggesektorens hovedaktører tager et aktivt medansvar for bestemte dele af planen. En af de mest presserende opgaver og højest prioriterede initiativer på kort sigt var et tæt, koordineret samspil mellem alle byggesektorens aktører og stimulering af efterspørgslen efter inddragelse af miljøhensyn i eksisterende og nyt byggeri.

Blandt byggeriets aktører er der stadig ikke enighed om, hvorvidt det er bygherren, entreprenøren, arkitekterne eller ingeniørerne, der har ansvaret og skal tage initiativet til at bygge bæredygtigt. En af konklusionerne på en konference afholdt foråret 2004 var, at enten må det være entreprenørerne, der stiller krav og gør det til en del af byggeprojektets projektbeskrivelse, eller også skal myndighederne gå forrest $\mathrm{og}$ sætte dagsordenen. ${ }^{66}$ Det blev samtidig pointeret, at et bredere samarbejde mellem byggeriets parter og myndigheder, bygherrer og leverandører er absolut nødvendigt i forhold til at arbejde systematisk med miljøhensyn. Inden for byggeri er der generelt tale om et område med et stort miljøpotentiale men samtidig et område med tradition for, at de mange aktører har hvert deres sprog og tilgang til miljøområdet med mangel på fælles mål og politikker samt enkle, gennemsigtige og brugbare værk- tøjer på miljøområdet, hvorfor afstanden fra »vi vil« til »vi gør«i forhold til bæredygtighed er meget stor.

\section{$\emptyset$ konomi}

En af de holdninger, der er forbundet med miljørigtigt byggeri, er, at det altid er dyrere end traditionelt byggeri.

I eksemplet fra Stillinge IF blev det dyrere at tage miljøhensyn i forhold til et traditionelt byggeri, i Jetsmark IF var der ingen fordyrelse af prisen, og i Humlum var den lave pris på halmbyggeriet et væsentligt parameter for at gennemføre projektet. Resultaterne fra en række fors $\emptyset$ gsbyggerier har vist, at det er muligt at lavet byøkologisk byggeri med væsentlige miljøfordele. Selvom det koster mere i anskaffelse, modsvares dette af besparelser på opvarmning, belysning og varmt vand ${ }^{67}$ Når der anlægges et totaløkonomisk perspektiv, behøver byøkologisk byggeri derfor ikke at være dyrere end konventionelt byggeri. Et lavt ressourceforbrug er især opnået for byggerier med brugerinddragelse, hvilket illustrerer vigtigheden af også at rette en indsats mod brugeradfærd udover de bygningsmæssige tiltag.

Det er sund fornuft at tage hensyn til den efterfølgende drift, når en bygherre planlægger og udfører et nyt byggeri, da halvdelen af alle omkostninger $\mathrm{i}$ relation til byggeriet ligger i driftsfasen. ${ }^{68}$

I praksis må det dog konstateres, at de totaløkonomiske overvejelser generelt ikke er slået igennem i nybyggeriet. ${ }^{69}$

At spare på ressourcerne er ofte også en $\emptyset$ konomisk besparelse, hvorfor det kan betale sig at inkludere miljøhensyn allerede fra starten på lige fod med фkonomien. Men det er nødvendigt at komme med nogle konkrete udregninger på, at en evt. ekstra udgift til investering i mere miljørigti- 
ge løsninger i anlægsfasen kan tjene sig hjem igen inden for en kort periode, ellers bliver det svært at overtale bygherren.

\section{Bliver fremtidens idratsanlag miljørigtigt?}

Idrættens og idrætsbyggeriets indflydelse på miljø, økonomi, sundhed og social velfærd kendes ikke, men det er en kendsgerning, at det et område med stigende aktivitetsniveau og en branche i vækst.

I dag ligger ansvaret for en mere bæredygtig udvikling af idrætsbyggeri med bl.a. inddragelse af miljøhensyn i både anlægs- og driftsfase ude hos den enkelte aktør.

Danmark har mindst 1000 idrætshaller og -anlæg, ca. 14.000 idrætsforeninger og omkring 2 mio. mennesker, der dyrker idræt. Det er ikke lykkedes at finde frem til mere end tre eksempler på miljørigtigt idrætsbyggeri, ni eksempler på miljømærkede idrætsfaciliteter og enkelte eksempler på anvendelse af internationale miljøstandarder. Herudover anvendes grønne regnskaber og miljøledelse i en række foreninger, og visse kommuner stiller krav om dette ved udførelse af særlig støjende eller arealkrævende sportsgrene.

Samlet set kan det konkluderes, at der ikke er stor efterspørgsel efter miljørigtigt idrætsbyggeri, hverken når der bygges nye anlæg eller ved den daglige drift.

De beskrevne initiativer og ordninger til miljøvenlig drift bygger på frivillighed og en markedsbaseret efterspørgsel. Der er mangel på viden om, at det kan lade sig gøre og på gode eksempler inden for området. Mange idrætsforeninger har ingen miljøpolitik, ligesom den er fraværende hos flere af idrættens organisationer.

Selvom efterspørgslen efter miljørigtigt idrætsbyggeri skulle stige, er der ikke meget hjælp at hente for de idrætsforeninger, der $\emptyset$ nsker at vide mere om dette område. Opbakning blandt idrættens organisationer til at underbygge en udvikling af idrætsbyggeriet $i$ en mere bæredygtig retning er begrænset og visse steder fraværende. Men idrætsorganisationerne kan være med til at tage et ansvar, hvis der er politisk vilje.

Kommunerne, som ejer hovedparten af idrætsanlæggene, har også mulighed for at vejlede og stille krav, når idrætsbyggeriet er offentligt eller offentlig støttet. Mange kommuner har udarbejdet standarder, retningslinier og vejledninger vedr. miljørigtigt byggeri, og disse kan bruges i det videre arbejde.

Miljørigtig projektering er endnu ikke en integreret del af byggeriet, miljø betragtes ikke som en naturlig del den arkitektoniske kvalitet, og rådgiverne er stadig ikke enige om at placere ansvaret og arbejde ud fra fælles retningslinier, hvilket stiller større krav til den idrætsforening, der ønsker et miljørigtigt byggeri, om at finde de arkitekter og ingeniører, som har den nødvendige ekspertise på området.

En stigende andel af den voksne befolkning dyrker idræt. De primære årsager til at deltage er sundhed, socialt samvær og fællesskab. Men der burde ikke være en modsætning mellem dette og samtidig at udvise miljømæssig ansvarlighed. Det handler i sidste ende om holdninger og adfærd.

$\varnothing$ konomien er en væsentlig parameter ved ny og ombygning af faciliteterne. Miljørigtigt byggeri behøver ikke at være dyrere set over et helt livsforløb, men det er nødvendigt at anvende en helhedsbetragtning og se på de totale økonomiske omkostninger ved både anlæg og drift af bygningerne. Der mangler konkrete eksempler på, at investeringerne kan tjene sig hjem igen i løbet af en kort årrække. 
Der er behov for synlighed, for viden og for markedsføring af »den gode historie «. Det handler om viden, oplysning, gode eksempler og masser af initiativer at hente inspiration fra. Samarbejde på kryds og tværs med ideer og udveksling af erfaringer, små og store projekter, samt økonomisk og politisk opbakning.

I Tyskland har man grebet chancen og gjort miljø til et centralt tema, der benyttes i formidlingsstrategi af verdensmesterskabet i fodbold med det formål at give arrangementet og landet et positivt »brand «. Den danske regering satser på at få flere store kulturarrangementer til landet, og det forventes at få en større økonomisk betydning for dansk turisme i fremtiden, så hvorfor ikke satse på en bæredygtig udvikling af idrætten til at understøtte dette formål?

Mulighederne er mange, men for at få miljørigtigt eller bæredygtigt idrætsbyggeri på dagsordenen i konkret handling er det nødvendigt med en stærk politisk vilje, økonomisk opbakning, udveksling af viden og erfaringer, nytænkning og samarbejde. Frivillige initiativer gør det ikke alene.

\section{Noter}

1 Birgitte Kleis, Big Business, I: Arkitekten; nr. 4 (København 2004), s. 7.

2 René Kural, Fremtidens Idræts- og kulturbyggeri - Mellem vision og virkelighed (København 2000).

3 Lokale- og Anlægsfondens facilitetsdatabase (2004) www.loa-fonden.dk.

4 Torben Fridberg, Kultur- og fritidsaktiviteter 1993, Socialforskningsinstituttet 94:6 (København 1994).

Knud Larsen, Idrætsdeltagelse i Danmark 2002 Et notat om Lokale- og Anlægsfondens spørgeskemaundersøgelse den voksne befolknings idrætsdeltagelse i 2002 (København 2003), s. 2-5.

5 EU-kommissionen, A Pan-EU survey on consumer attitudes to physical activity, body weight and health (Brussel 1999).

PLS Rambøll Management, Befolkningens motivation og barrierer for fysisk aktivitet - Resumé (København 2003).

6 DGI's hovedbestyrelse, DGI mod 2010, s. 7-9 www.dgi.dk.

7 Birgitte Kleis, Big Business, I: Arkitekten; nr. 4 (København 2004), s. 7.

René Kural, Idræt som katalysator for byudviklingen, I: Arkitekten; nr. 4 (København 2004) s. 8-13

8 René Kural, Idræt som katalysator for byudviklingen, I: Arkitekten; nr. 4 (København 2004) s. 8-14.

9 Idrætsfonden Danmarks effektanalyser af større internationale idrætsbegivenheder i Danmark, maj 2004, www.idraetsfonden.dk.
10 Statens Byggeforskningsinstitut, Byggeri set i et livscyklusperspektiv, pressemeddelelse 12. april (København 1996).

11 Carl Bro, Affaldsforebyggelse i Danmark - status for den danske indsats, Orientering fra Miljøstyrelsen nr. 14, København 2000), s. 30-34.

12 Regeringen, Danmarks nationale strategi for bæredygtig udvikling, fælles fremtid - udvikling i balance, Indikatorrapport, (København 2002), s. 74-75.

13 Transportområdet Vejdirektoratet, TU 1998-1999, Resultater fra Transportvaneundersøgelsen, (København 2001), s. 25-25.

14 Peter Troelsen, Det er dyrt at være miljøbevidst, I: Ungdom \& Idræt nr. 33 (Vejle 1998).

15 Jonna Toft, Grønt klubhus får miljøpris, DGI årsmøde 1998 (København 1998).

16 Karen Balling Radmer, Jetsmark IF får grøn pris, DGI årsmøde 2000 (Fugls $\varnothing 2000$ ).

17 Danske Gymnastik- og Idrætsforeninger, Grøn pris til nordjysk idrætsforening, pressemeddelelse, (Fugls $\varnothing$ den 3. november 2000).

18 Sten Bille, Halmhal sikrer vintertennis, Ungdom \& Idræt nr. 31 (Vejle 2003).

19 Informations-Gemeinschaft Passivhaus Deutschland, Qualitätskriterien für Passivhäuser, www.igpassivhaus.de.

20 Birgitte Kleis, Big Business, I: Arkitekten; nr. 4 (København 2004), s. 7.

Helmut Krapmeier og Eva Müller, Energi Institut Voralberg, Østrig, Passiv Haus - et super lavener- 
gihus I: Medlemsblad for Foreningen Dansk Byøkologi nr. 1 (Århus 2002). Bygningsreglement 1995, RGM nr. 4002 af 13. februar 1995 (København 1995).

21 Ralf Bermich und Patrick Lubs, Neubau einer Passivhaus-Turnhalle für die Kurpfalzschule in Heidelberg-Kirchheim, (Heidelberg, Tyskland 2004).

22 Ragnhild Bjarttun, Kine Marie Berg Laksaa og Geir Lindahl, OL i Troms $\emptyset$ - Hvordan påvirkes miljøet i forbindelse med Lekene? Elevarbeid Idrettlinja Frydenlund vgs. (Norge 2004).

23 Greenpeace, »Greenpeace Olympic Environmental Games -A Guide to Sustainable Events « (2000).

24 Greenpeace, How green the games - a Greenpeace assessment of the environmental performance of the Athens 2004 Olympics (July 2004).

25 Den Grønne Nøgle, Miljødiplom til Idrætsanlæg, Ansøgningsskema (København 2004).

26 Halinspektørforeningen, »Den grønne nøgle, læs mere og download et kriteriesæt«, Nyheder 15. april 2004 på hjemmesiden: www.halinpektorerne.dk.

27 Committed to Green Foundation Strategic Objectives Golf www.committedtogreen.org.

28 Green Network, Medlemmer (offentlige), www.greennetwork.dk.

29 Miljøledelsesstandarden ISO 14001, Miljøstyrelsen, www.mst.dk. Introduktion til EMAS, Miljøstyrelsen, www.mst.dk.

30 Kulturministeriet, Idræt, www.kulturministeriet.dk.

31 Danmarks Idræts-Forbund, Politisk Program Miljø og fysisk planlægning, www.dif.dk.

32 Dorthe O. Andersen, miljøkonsulent i Danmarks Idræts-Forbund, personlig meddelelse, (Brøndby, juni 2004).

33 Danmarks Idræts-Forbund, Miljørigtigt idrætsbyggeri - en vejledning i miljørigtigt idrætsbyggeri (endnu ikke publiceret).

34 Danmarks Idræts-Forbund, Natur- og miljøprisen går til? DIF-Nyt 25. februar 2004 www.dif.dk.

35 Miljømagasinet - OL, P1 Morgen, Vært Katrine Nyland Sørensen, den 13. august 2004 kl. 06:56.

36 Steen Tinning, politisk konsulent i Danske Gymnastik- og Idrætsforeninger, personlig meddelelse (Vejle, juni 2004).

37 Steen Bille, Miljøarbejde går i stå. Regeringen stopper grønne initiativer i DGI Roskilde, I: Ungdom \& Idræt nr. 2 (Vejle 2002).

38 Steen Tinning, politisk konsulent i Danske Gymnastik- og Idrætsforeninger, personlig meddelelse (Vejle, juni 2004).
39 Bjarne Nissen, Millionbeløb til lokale idrætsfaciliteter, pressemeddelelse (Vejle, den 15. januar 2003).

40 Birger Kyhl, planlægningschef i Team Danmark, personlig meddelelse (Brøndby, juli 2004).

41 Karin Christiansen, Miljøvenligt byggeri - praktiske råd om nybygning, tilbygning og ombygning (København1998).

42 Holger Kortbek, konsulent i Lokale- og Anlægsfonden, personlig meddelelse (København, juni 2004).

43 Strategi for Lokale- og Anlægsfonden 2004-2006 (København 2003).

44 Internal Olympic Committee - Sport and Environment Commision, Olympic Movements - Agenda 21 - Sport for sustainable development (1996).

45 Öko-Institut e.V., Green Goal - Environmental goals for the 2006 FIFA World Cup - Background paper on the concept phase (Berlin 2003).

46 Peter Ejsing, Miljømanual - krav og muligheder ved byfornyelse og støttet boligbyggeri (Ålborg 2001). Kolding Kommune, Økologi i planlægning og byggeri - retningslinier i Kolding Kommune (Kolding 1999).

Vejle Kommune, SÅDAN GØR DU - når du bygger $\varnothing$ kologisk/miljørigtigt (Vejle 2000). Esbjerg Kommune, Miljørigtige tiltag når du bygger (Esbjerg 2002).

47 Københavns Kommune, Miljøkontrollen, Miljøorienteret byfornyelse og nybyggeri (København 2001). Hillerød Kommune, Standard for miljørigtigt byggeri- og anlæg i Hillerød Kommune, version 2004 (Hillerød 2004).

48 Bekendtgørelse af lov om planlægning (LBK nr. 763 af 11. september 2002) kapitel 5.

49 Ove Mørck, Jørn S. Holm, Marie Woge Nielsen, Lotte Roed, Jan Poulsen, Lars Berndt: Bæredygtighed i lokalplaner - et idé- og debatoplæg (Nordsjælland 2002).

50 Lone Ahrentzen, Birgitte Hoffmann og Søren Gabriel, Bæredygtigt nybyggeri i Glostrup Kommune, Medlemsblad for Foreningen for Dansk Byøkologi nr. 4. (Vejle 2001).

51 Bekendtgørelse af lov om planlægning (LBK nr. 763 af 11. september 2002) paragraf 33.

52 Jan Poulsen, Jette Hagensen, Bæredygtigt byggeri - et idé- og debatoplæg (Frederikssund 2002). Pandrup Kommune, Miljøplan 2002 (Pandrup 2000).

53 Dansk Center for Byøkologi www.dcue.dk

54 Europa-parlamentets og rådets direktiv 2002/91/ EF af 16. december 2002 om bygningers energimæssige ydeevne.

55 Energistyrelsen, Energipolitisk redegørelse - фko- 
nomi- og erhvervsminsterens redegørelse i henhold til lov om energipolitiske foranstaltninger (København 2003). S. 1-13.

56 BPS-centret, Håndbog i miljørigtig projektering, Bind 1-2, BPS-Publikation nr. 121 (1998).

57 Pernille Hedehus, Miljøvurdering af byggeri Miljøprojekt nr. 686 (København 2002).

58 Akademisk Arkitektforening, Miljøpolitik (København 2000).

59 Rie Øhlenschlæger, Miljørigtigt byggeri og miljørigtige byer - arkitektonisk kvalitet er også miljøkvalitet (København 2003).

60 Arkitektur og bæredygtighed i dansk boligbyggeri (SHE), International Arkitektforening (København 2003).

61 Informations-Gemeinschaft Passivhaus Deutschland, Qualitätskriterien für Passivhauser, www.igpassivhaus.de.

62 Akademisk Arkitektforening, kursus i Miljøbevidst arkitektur 2004, www.aa.dk.

\section{Litteratur}

Ahrentzen, Lone, Birgitte Hoffmann og Søren Gabriel: Bæredygtigt nybyggeri i Glostrup Kommune. Medlemsblad for Foreningen for Dansk Byøkologi nr. 4. Vejle 2001.

Arkitektur og bæredygtighed i dansk boligbyggeri (SHE). International Arkitektforening København 2003.

Bekendtgørelse af lov om planlægning (LBK nr. 763 af 11. september 2002) kapitel 5. Og paragraf 33.

Bermich, Ralf und Patrick Lubs Neubau einer Passivhaus-Turnhalle für die Kurpfalzschule in Heidelberg-Kirchheim. Heidelberg, Tyskland 2004.

Bille, Steen: Miljøarbejde går i stå. Regeringen stopper grønne initiativer i DGI Roskilde, I: Ungdom \& Idræt nr. 2. Vejle 2002.

Bjarttun, Ragnhild, Kine Marie Berg Laksaa og Geir Lindahl: OL i Troms $\varnothing$ - Hvordan påvirkes miljøet $\mathrm{i}$ forbindelse med Lekene? Elevarbeid Idrettlinja Frydenlund vgs. Norge 2004.

BPS-centret: Håndbog i miljørigtig projektering, Bind 1-2. BPS-Publikation nr. 121. 1998.

Brundtlandkommissionen: Vores Fælles Fremtid, FNforbundet og Mellemfolkeligt Samvirke. København 1987, s. 20.

Byggepanelet: Handlingsplan for en bæredygtig udvikling i den danske byggesektor. København 2001.

Bygningsreglement 1995, RGM nr. 4002 af 13. februar 1995. København 1995.

Carl Bro: Affaldsforebyggelse i Danmark - status for
63 Rie Øhlenschlæger, konsulent i Dansk Center for Byøkologi. (Vejle juli 2004).

64 Byggepanelet, Handlingsplan for en bæredygtig udvikling i den danske byggesektor (København 2001).

65 Byggepanelet, Handlingsplan for en bæredygtig udvikling i den danske byggesektor (København 2001).

66 Camilla Hjerl, »Bæredygtigt byggeri - en by i Rusland?«. I: Teknologidebat.dk oktober 2002 (København 2002).

67 Jørn Dinesen et al. Bæredygtigt byggeri betaler sig - evaluering af ØKOHUS 99 (København 2001), s.7-8.

68 Birgitte Dyrvig Carlsson og Hanne Strøh Sabroe, Halvdelen af et byggeris totaløkonomi ligger i driftsfasen I: Byggeforum nr. 2 (Middelfart 2004).

69 Hans Bjerregård Rådgivning ApS, 12 Byøkologiske fors $\varnothing$ gsbyggerier - Erfaringer og anbefalinger (København 2001).

den danske indsats, Orientering fra Miljøstyrelsen nr. 14. København 200, s.74-75.

Carlsson, Birgitte Dyrvig og Hanne Strøh Sabroe: Halvdelen af et byggeris totaløkonomi ligger $i$ driftsfasen. I Byggeforum nr. 2. Middelfart 2004.

Christiansen, Karin: Miljøvenligt byggeri - praktiske råd om nybygning, tilbygning og ombygning. København1998.

Danmarks Idræts-Forbund: Miljørigtigt idrætsbyggeri - en vejledning i miljørigtigt idrætsbyggeri, (endnu ikke publiceret).

Danske Gymnastik- og Idrætsforeninger: Grøn pris til nordjysk idrætsforening. Pressemeddelelse. Fugls $\varnothing$ den 3. november 2000.

Dinesen, Jørn et. al.: Bæredygtigt byggeri betaler sig evaluering af ØKOHUS 99. København 2001, s.7-8.

Ejsing, Peter: Miljømanual - krav og muligheder ved byfornyelse og støttet boligbyggeri. Ålborg 2001.

Energistyrelsen: Energipolitisk redegørelse - økonomi- og erhvervsminsterens redegørelse.

Esbjerg Kommune: Miljørigtige tiltag når du bygger. Esbjerg 2002.

EU-kommissionen: A Pan-EU survey on consumer attitudes to physical activity, body weight and health. Brussel 1999.

Europaparlamentets og -rådets direktiv 2002/91/EF af 16. december 2002 om bygningers energimæssige ydeevne. 
Fremtidens Idræts- og kulturbyggeri - Mellem vision og virkelighed. København 2000.

Fridberg, Torben: Kultur- og fritidsaktiviteter 1993, Socialforskningsinstituttet 94:6. København 1994.

Greenpeace: Greenpeace Olympic Environmental Games - A Guide to Sustainable Events. 2000.

Halmhal sikrer vintertennis. Ungdom \& Idræt nr. 31. Vejle 2003.

Hedehus, Pernille: Miljøvurdering af byggeri - Miljøprojekt nr. 686. København 2002.

Hillerød Kommune: Standard for miljørigtigt byggeri- og anlæg i Hillerød Kommune, version 2004. Hillerød 2004.

Hjerl, Camilla: Bæredygtigt byggeri - en by i Rusland? I: Teknologidebat.dk oktober 2002. København 2002.

How green the games - a Greenpeace assessment of the environmental performance of the Athens 2004 Olympics. July 2004.

Internal Olympic Committee - Sport and Environment Commision: Olympic Movements - Agenda 21 - Sport for sustainable development. 1996.

Kleis, Birgitte, Big Business, I: Arkitekten; nr. 4. København 2004, s. 7.

Kolding Kommune: Økologi i planlægning og byggeri - retningslinier i Kolding Kommune. Kolding 1999.

Krapmeier, Helmut og Eva Müller: Energi Institut Voralberg, Østrig, Passiv Haus - et super lavenergihus. I: Medlemsblad for Foreningen Dansk Byøkologi nr. 1. Århus 2002.

Kulav, René: Idræt som katalysator for byudviklingen, I: Arkitekten; nr. 4. København 2004, s. 8-13.

Københavns Kommune: Miljøkontrollen. Miljøorienteret byfornyelse og nybyggeri. København 2001.

Larsen, Knud: Idrætsdeltagelse i Danmark 2002 - Et notat om Lokale- og Anlægsfondens spørgeskemaunders $\emptyset$ gelse vedr. den voksne befolknings idrætsdeltagelse i 2002. København 2003, s. 2-5.

Miljø- og Energiministeriet: Natur- og Miljøpolitisk redegørelse 1999. København 1999, s. 451-459.

Miljømagasinet - OL, P1 Morgen. Vært Katrine Nyland Sørensen. Den 13. august 2004 kl.06:56.

Miljøpolitik København 2000.

Miljørigtigt byggeri og miljørigtige byer - arkitektonisk kvalitet er også miljøkvalitet. København 2003.

Miljøstyrelsen nr. 14. København 2000, s. 30-34.

Mørck, Ove, Jørn S. Holm, Marie Woge Nielsen, Lotte Roed, Jan Poulsen, Lars Berndt: Bæredygtighed i lokalplaner - et idé- og debatoplæg. Nordsjælland 2002.

Nissen, Bjarne: Millionbeløb til lokale idrætsfacilite- ter. Pressemeddelelse. Vejle, den 15. januar 2003. Pandrup Kommune: Miljøplan 2002. Pandrup 2000.

PLS Rambøll Management: Befolkningens motivation og barrierer for fysisk aktivitet - Resumé. København 2003.

Poulsen, Jan, Jette Hagensen: Bæredygtigt byggeri et idé- og debatoplæg. Frederikssund 2002.

Radmer, Karen Balling: Jetsmark IF får grøn pris. DGI årsmøde 2000. Fuglsø 2000.

Regeringen: Danmarks nationale strategi for bæredygtig udvikling, fælles fremtid - udvikling i balance. Indikatorrapport. København 2002, s. 74-75.

Statens Byggeforskningsinstitut: Byggeri set i et livscyklusperspektiv. Pressemeddelelse 12. april København 1996.

Strategi for Lokale- og Anlægsfonden 2004-2006. København 2003.

Tinning, Steen, politisk konsulent i Danske Gymnastik- og Idrætsforeninger, personlig meddelelse. Vejle, juni 2004.

Toft, Jonna: Grønt klubhus får miljøpris. DGI årsm øde 1998. København 1998.

Transport- Transportområdet, Vejdirektoratet: TU 1998-1999, Resultater fra Transportvaneundersøgelsen. København 2001, s. 25-25.

Troelsen, Peter: Det er dyrt at være miljøbevidst, I: Ungdom \& Idræt nr. 33. Vejle 1998.

Vejle Kommune: SÅDAN GØR DU - når du bygger $\emptyset \mathrm{kologisk} /$ miljørigtigt. Vejle 2000.

Öko-Institut e.V.: Green Goal - Environmental goals for the 2006 FIFA World Cup - Background paper on the concept phase. Berlin 2003.

\section{Samtaler}

Andersen, Dorthe O. (miljøkonsulent i Danmarks Idræts-Forbund) personlig meddelelse. Brøndby, juni 2004.

Kortbek, Holger (konsulent i Lokale- og Anlægsfonden) personlig meddelelse. København, juni 2004.

Kyhl, Birger (planlægningschef i Team Danmark) personlig meddelelse. Brøndby, juli 2004.

Øhlenschlæger Rie (konsulent i Dansk Center for Byøkologi) (Vejle juli 2004).

\section{Hjemmesider}

Akademisk Arkitektforening: Kursus i Miljøbevidst arkitektur 2004, www.aa.dk

Committed to Green Foundation Strategic Objectives Golf www.committedtogreen.org.

Danmarks Idræts-Forbund: Natur- og miljøprisen går til? DIF-Nyt 25. februar 2004. Politisk Program Miljø og fysisk planlægning, www.dif.dk. 
Dansk Center for Byøkologi. www.dcue.dk.

Den Grønne Nøgle: Miljødiplom til Idrætsanlæg. Ansøgningsskema. København 2004.

DGI's hovedbestyrelse, DGI mod 2010, s. 7-9 www.dgi.dk.

Green Network, Medlemmer (offentlige), www.greennetwork.dk.

Halinspektørforeningen: Den grønne nøgle, læs mere og download et kriteriesæt. Nyheder 15. april 2004 på hjemmesiden: www.halinpektorerne.dk.

Idrætsfondens Danmarks effektanalyser af større in- ternationale idrætsbegivenheder i Danmark, maj 2004, www.idraetsfonden.dk.

Informations-Gemeinschaft Passivhaus Deutschland: Qualitätskriterien für Passivhäuser. www.ig-passivhaus.de.

Kulturministeriet. Idræt. www.kulturministeriet.dk.

Lokale- og Anlægsfondens facilitetsdatabase (2004) www.loa-fonden.dk.

Miljøstyrelsen: Introduktion til EMAS. www.mst.dk. Miljøstyrelsen: Miljøledelsesstandarden ISO 14001. www.mst.dk. 